\title{
PRELIMINARY RESULTS OF THE TEMPERATURE DISTRIBUTION MEASUREMENTS AROUND THE VERTICAL GROUND HEAT EXCHANGERS TUBES
}

\begin{abstract}
The paper presents the preliminary results of the temperature distribution to a depth of $100 \mathrm{~m}$ in the two selected vertical geothermal wells during operation of the heat pump and ground temperature measurement without vertical ground probes work. Research was carried out from the third decade of December to the end of February. The wells are the lower energy source for two heat pumps brine/water type with heating power of $117.2 \mathrm{~kW}$ each and $95.9 \mathrm{~kW}$ cooling capacity installed in the building of The Faculty of Civil and Environmental Engineering, Bialystok University of Technology in Bialystok. With heat pumps work 52 vertical ground probes to a depth of $100 \mathrm{~m}$ each. The article presents the way of making probes equipped with 30 digital temperature sensors to record the temperature distribution in the vertical probes and in the ground and it shows the way of making the test bench using the groundwater wells with vertical probes. The average coefficient of performance $C O P$ of the heat pump $H P$ in the months of January and February has been designated.
\end{abstract}

Keywords: temperature distribution, vertical ground probe, ground, heat pump, borehole

\section{Introduction}

Resources of clean and renewable energy are paying more and more attention due to their advantages compared to fossil fuels, which have a significant impact on global warming and pollution. As one of the main options for replacing conventional energy sources, geothermal energy is becoming increasingly attractive due to its wide availability, low operating costs and low $\mathrm{CO}_{2}$ emissions [1]. Technological development together with the increasing awareness of Earth protection significantly influenced the improvement of buildings in terms of energy demand. This allowed the use of low-temperature heating that perfectly matches the heat source which is the heat pump $(H P)$. Heat pumps extract energy from nature (lower source) and convert it into energy for central heating and for heating domestic hot water. Therefore, it is important to choose the right source of heat, e.g. air or ground. When it comes to air, the matter of choosing the lower heat source is quite simple. However, when it comes to ground, the situation is more serious. Vertical ground heat exchangers (VGHE) are the most common borehole heat exchangers $(B H E)$ used in buildings [2] due to their higher efficiency [3]. In $B H E$, the fluid circulates in U-shaped pipes, which can be single or double U-shaped pipes, and the remaining part of the borehole is filled with a filler material, called grout, usually made of bentonite, quartz with sand or

\footnotetext{
${ }^{1}$ Department of Heating, Ventilation, Air Conditioning, Faculty of Civil Engineering and Environmental Sciences, Bialystok University of Technology, ul. Wiejska 45E, 15-351 Białystok, Poland, phone +48 857469635 , fax +48 8574695 76, email: j.piotrowska@ pb.edu.pl
} 
only a water mixture [4]. Quartz ensures higher thermal conductivity of the grout, and bentonite provides sealing and blinding properties [5]. Due to the earthworks, the dimensions of the ground heat exchanger should be properly selected (calculated), its length. Vertical wells are quite expensive so it is necessary to determine their required number. Too small will result in excessive "discharge" and lack of time for its regeneration in the summer. Too much of them will generate unnecessary costs. Vertical ground heat exchangers are one of the most important parts of ground-connected heat pump systems. Accurate modelling of vertical ground heat exchangers will reduce the initial investment cost and maximize the economic benefits that are very important for the popularization of ground source heat pumps. The effect of layered soil profiles should be considered in many applications, such as energy stacks, which must know the temperature changes in each soil layer to account for the effect of temperature on mechanical properties in the geotechnical design. Analytical models assuming a homogeneous soil profile cannot accurately predict temperature changes in different soil layers [6]. It is therefore advantageous to calculate the lower heat source parameters as accurately as possible. Further attempts are being made to solve this problem analytically or using computer simulations [7-21], but so far there is no universal formula. For calculations and simulations, real measurement results are needed, e.g., ground temperatures in the vicinity of a vertical ground heat exchanger during its operation and during regeneration. A number of studies [22-28] have been conducted to assess $B H E$ performance in heat pump systems. All of these studies reported the effects of $B H E$ based on an assessment of $C O P$ improvement in these systems.

BHEs are a key technological element of geothermal energy systems, and modelling their behaviour has attracted a lot of attention. The technical challenge in designing ground heat exchanger systems is primarily the ability to predict long-term temperature trends in well groups. This inevitably requires computer models implemented in the design software or tools for simulating thermal systems [29, 30]. Very often the scientific literature raises issues of analytical or numerical optimization of vertical ground heat exchangers as lower energy sources for heat pumps for various construction systems, geothermal and climatic sizes and conditions to minimize changes in ground temperature and improve the efficiency of heat pumps $[7,8]$.

Forecasting of ground temperature profile is required for many energy applications, such as ground source heat for heat pumps, energy storage, heating and cooling of buildings. Knowledge of $B H E$ performance is essential to optimize the design and performance of ground source heat pump systems. Many studies look for a function describing the soil temperature profile, the most popular are those proposed by Kasuda and Archenbach, who provide a sinusoidal change in soil temperature at various depths as a function of average temperature. The amplitude of the change decreases with the depth, depending on the soil characteristics, until the temperature reaches one value [31]. This relationship is used in numerical methods. More on numerical methods used in calculations of ground heat exchange can be found in [9, 32-36], analytical and semi-empirical methods in [10, 37]. Most analytical and numerical methods are not always able to actually predict the temperature distribution in the ground. This is due to the difficulty in determining the exact boundary conditions of the ground's physical properties. In practice, a semi-empirical method is used to measure temperature changes at the earth's surface in a given location [11]. The literature discusses an experimental study of the temperature distribution in ground [23, 38-40]. In case where heat is received or delivered to the ground by a vertical ground heat exchanger, there is distortion of the thermal 
equilibrium and in addition a significant decrease in the undistorted, natural ground temperature occurs [41], further around the well, hopper temperature is formed [42], i.e. the ground low temperature area. Therefore, it is important to maintain a minimum distance between vertical ground heat exchangers, depending on the depth of the well. In practice, they are from 6 to $10 \mathrm{~m}$. Research on the temperature distribution around a vertical ground heat exchanger $50 \mathrm{~m}$ in depth, conducted by Rybach and Sanner [43] indicate the formation of the temperature in the hopper range, which is affected by the conductivity and heat capacity of individual layers of the geological profile of the earth. Heterogeneous isotherms are also found in the ground around the vertical heat exchanger. $\mathrm{Ma}$ et al. investigated the impact of groundwater migration on VGHE, heat exchange between ground heat exchangers and changes in the surrounding soil from heat conduction to coupled conduction-convection mode. To study the effect of the aquifer on the soil temperature distribution around the ground heat exchanger, a realistic model was established and numerically solved, including the ground heat exchanger and alternatively arranged aquifers and aquifuge layers [44]. The paper presents preliminary results of temperature distribution to a depth of $100 \mathrm{~m}$ in two selected VGHEs during heat pump operation in January and February and soil temperature measurement when the exchanger is not working. There is no such study of real objects in the wells of the heat source. Similar temperature measurements in the surroundings of the vertical ground heat exchanger were carried out by Michalski and Klitzsch [45], however, in their work it was used to determine the ground water flow through the cross-section of this heat exchanger. They presented the first application of a temperature sensor module (TSM) in their design for calculating the speed and direction of groundwater flow in well heat exchangers $(B H E)$. Adamovsky et al. investigated the work of VGHEs parameters in rock massive to the $100 \mathrm{~m}$ in depth, but they measured temperatures only in 5 points of VGHE [46]. This work presents the results of temperature measurements around VGHE $100 \mathrm{~m}$ in depth using 30 temperature sensors.

According to conservative estimates, geothermal energy will meet $3 \%$ of electricity demand and $5 \%$ of heating demand worldwide in 2050 [47].

\section{Description of the lower heat source on the campus of Bialystok University of Technology}

Bialystok is situated in the north-eastern part of the Polish in the North-Podlasie Lowland occupies an area of The Bialystok Height. The city belongs to the "Green Lungs of Polish". The geographical coordinates of the area designated for vertical wells are: latitude from $53^{\circ} 07^{\prime} 1.9^{\prime \prime}$ to $53^{\circ} 07^{\prime} 8.94^{\prime \prime} \mathrm{N}$ and longitude $23^{\circ} 9^{\prime} 0.72^{\prime \prime}$ to $23^{\circ} 9^{\prime} 14.06^{\prime \prime E}$.

Heat source in the form of vertical geothermal probes for the two heat pumps brine water type, each with a capacity of $117.2 \mathrm{~kW}$ heating and cooling capacity of $95.9 \mathrm{~kW}$ has been done on the campus of the Bialystok University of Technology (BUoT). The calculation of the vertical probes selection was performed assuming that the capacity of heat source is on average $35.0 \mathrm{~W} / \mathrm{m}$ probe length [48]. This coefficient was adopted on the basis of the Thermal Response Test (TRT) of the soil for the $100 \mathrm{~m}$ deep vertical ground probe. Based on the recorded measurement lasting 44 hours 40 minutes, the effective thermal conductivity coefficient of the soil was determined as $\lambda=1.76 \mathrm{~W} /(\mathrm{m} \cdot \mathrm{K})$. On its basis and with the assumed design operating time of the installation not exceeding $2000 \mathrm{~h} /$ year, the possible efficiency of heat consumption from $100 \mathrm{~m}$ of vertical ground probe per year is $35.4 \mathrm{~W} / \mathrm{m}$. In order to provide the required power of the heat source 
52 vertical wells are designed with a depth of $100 \mathrm{~m}$ each, with a total power of $182 \mathrm{~kW}$. The total length of vertical wells is $5200 \mathrm{~m}$, the distance between the ground probes assumed 10 meters. Assumed vertical probe made of cross-linked polyethylene diameter $40 \mathrm{~mm} \cdot 3.7 \mathrm{~mm}$.

Vertical distribution of 52 probes on the campus of BUoT is shown in Figure 1. The two collector wells are also designed for 26 sections, each equipped with a rotameter with flow range $8-25 \mathrm{dm}^{3} / \mathrm{min}$. The two of the 52 vertical ground probes, are selected, indicated in Figure 1, as P41 and P42 for which the tests of the temperature distribution are conducted to a depth of $100 \mathrm{~m}$ during their operation.

Figure 1 shows the location of 52 vertical ground probes at a depth of $100 \mathrm{~m}$, each labelled from P21 to P72.

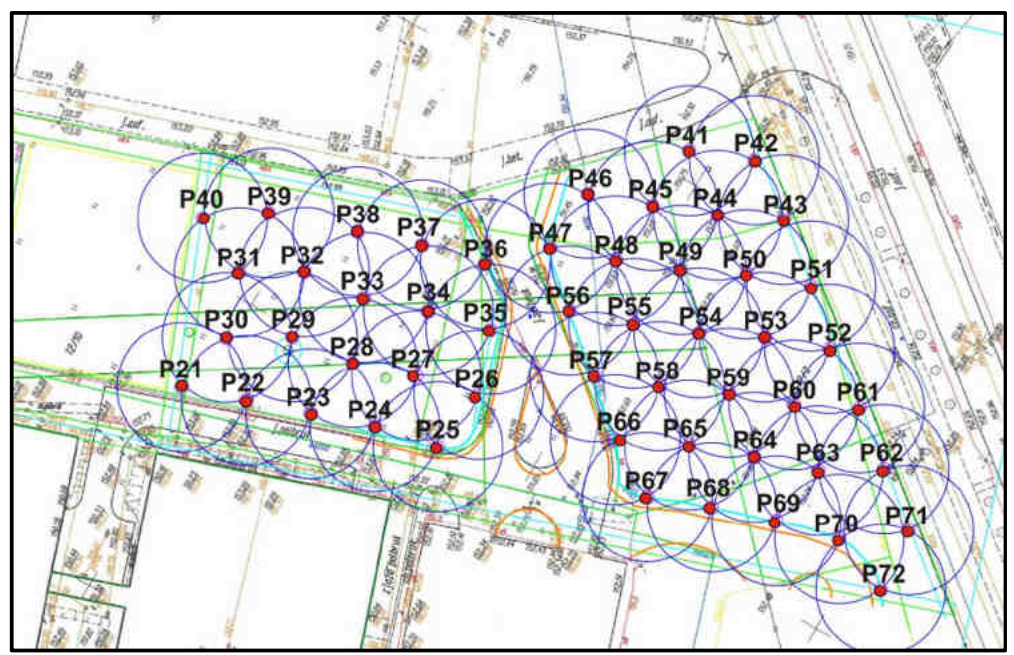

Fig. 1. View of 52 vertical probes distribution of land with a depth of $100 \mathrm{~m}$ each on Bialystok University of Technology Campus. Tested vertical probes wells are marked P41 and P42 [49]

\section{Method of making probes}

For the measurement of the vertical probes temperature to depth of 100 meters and for monitoring the temperature of the ground without heat load, based on the Piotrowska-Woroniak and Gajewski concept together with the company Elektrokomplex [50] the multi-point measurement system has been developed. The system was developed based on an initial concept assumes the measurement and simultaneous collection of measurement data from 236 sensors located on eight measurement probes, including four ground probes with a length of $100 \mathrm{~m}$ and 4 ones with a length of $50 \mathrm{~m}$. Expected integration of the system with SCADA (Supervisory Control And Data Acquisition) enables visualization, data collection and supervising the recording of measurements and processes in the lower heat source. Also assumed independent sensors buses so that in the event of failure of one of the sensors, the measuring temperature in the borehole further could be realized. At the same time used sensors should be resistant to moisture and resistant to pressure up to $10^{6} \mathrm{~Pa}$, with a measuring range from 243.0 to $293.0 \mathrm{~K}$. 
In the first phase of the project the measurement of the temperature in the ground, based on an analog system solution was considered. The implementation of the measurement was assumed using type $\mathrm{T}$ thermocouples $(\mathrm{Cu}-\mathrm{CuNi})$ with an accuracy of $\pm 0.1 \mathrm{~K}$ in the temperature range 243.0 to $333.0 \mathrm{~K}$. However, due to the large number of sensors provided and a considerable distance from measuring points to the building the solution based on the digital temperature measurement was applied.

The adopted solution has enabled seamlessly in one system to use a large number of sensors without the need to connect each sensor individually with separate connection cable to the measuring module, as would be the case of an analog system. Also avoided losses on cable length and electromagnetic interference that may occur.

At the design stage of the ground probes [50] the multi-point temperature measurement system using a digital temperature sensors DS18B20 placed in a metal housing Dallas Semiconductor company was applied, which was subsequently approved for implementation. The parameters of used sensors are shown in Table 1.

Parameters of digital sensors DS18B20 Dallas Semiconductor's used for temperature measurement

\begin{tabular}{|c|c|}
\hline Supply & from 3.0 to $5.5 \mathrm{~V}$ \\
\hline Measuring range & from 218.2 to $398.2 \mathrm{~K}$ \\
\hline Resolution & from 9 to 12 bits $(273.2 \mathrm{~K}$ at $12 \mathrm{bits})$ \\
\hline Probe dimensions & diameter: $6 \mathrm{~mm}$, length: $51 \mathrm{~mm}$ \\
\hline Degree of cover protection & IP65 \\
\hline
\end{tabular}

For research purposes Elektrokomplex Bialystok has made eight probes, four probes with a length of $100 \mathrm{~m}$ for temperature measurement in vertical boreholes and four probes with a length of $50 \mathrm{~m}$ to measure the temperature at oblique wellbores. The 236 sensors DS18B20 were grouped into 30 units for each borehole length of $100 \mathrm{~m}$ and the 29 units on a $50 \mathrm{~m}$ length of the hole thus creating a probe. Each of probes, made for special order, includes sensors mounted split into four separate 1-Wire bus. On each bus measurement is 8 or 7 DS18B20 digital sensors arranged alternately at equal intervals. The use of separate 1 -Wire bus is designed to enhance system reliability.

The respective digital temperature sensors in the probe are connected to adapters and communicate with the control system via the 1-Wire bus. The adapters are connected to each other and to the PLC by means of a separate communication bus RS-485 [50]. Each sensor has a unique 64-bit serial number used to identify a particular sensor, located in ROM. The stand for the sensors identification is shown in Figure 2.

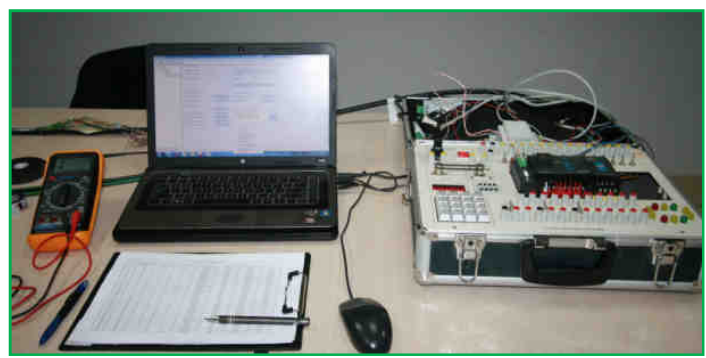

Fig. 2. The test-stand to identify sensors [photo: Elektrokomplex] 
Temperature sensors are soldered to the main bus without physical cutting, and the places of joining the sensors are insulated and protected with epoxy resin, providing complete hermetic seal. Sections connecting the bus with additional sensors were secured with thick-walled heat shrink with hot melt adhesive cover, providing insulation, sealing and mechanical protection of mounting location and connections of the sensors themselves.

Figure 3 shows how the sensors are connected to the probe with a length of $100 \mathrm{~m}$ and the execution of their isolation.

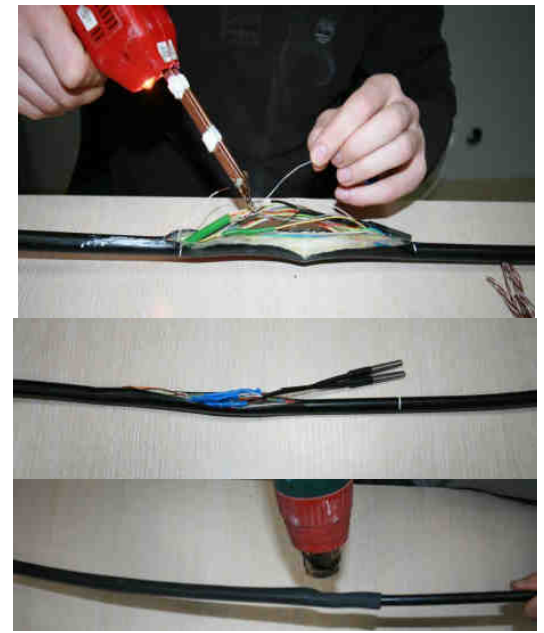

Fig. 3. The order of the work performed during the installation of temperature sensors DS18B20 of the probe with a length of $100 \mathrm{~m}$ [photo: Elektrokomplex]

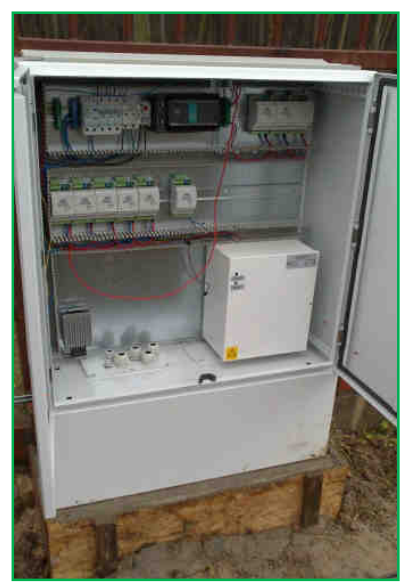

Fig. 4. View of the measurement and distribution box equipped with recorders measuring up to 120 sensors [photo: author]

Prior to introduction into the borehole each probe was before calibrated. Calibration was performed at the melting point of ice water, double distilled, i.e. $273.2 \mathrm{~K}$, for each 
sensor mounted no the probe is given a patch that is included in the processing of measurement data.

Measurement data collected from the 4 probes are transferred by dedicated circuits to the measurement and distribution box. Figure 4 shows the measurement and distribution box equipped with recorders for 120 temperature sensors.

In order to monitor the operation of lower heat source SCADA software was used to allow for a full archive of measurement data, generate reports daily, monthly, or yearly basis. Visualization and supervision over the work of the whole system is performed remotely from the website.

\section{Description of the measuring stand adaptation}

To create the stand for measuring the temperature at various depths with vertical ground probes were adapted two boreholes (according to the conceptual guidelines developed by J. Piotrowska-Woroniak and A. Gajewski) - marked in Figure 5 as P41 and $\mathrm{P} 42$, where during drilling works with the vertical ground probe, the probe with 30 sensors was introduced. The measuring probe with sensors is located approximately $5 \mathrm{~cm}$ from the operating ground heat exchanger pipes. Additionally, halfway between the boreholes P41 and P42 and between P42 and P44, are planned two additional boreholes, which were also introduced measurement probes equipped with sensors, indicated in Figure 5, as SP1. Installation of additional measurement system will be responsible for monitoring and verification of the effect that probes have in the course of their work, as well as during the regeneration of the ground in the spring and summer, when the probes are no longer working. The current design guidelines require that the spacing between vertical probes up to $100 \mathrm{~m}$ in depth should be $10 \mathrm{~m}$.

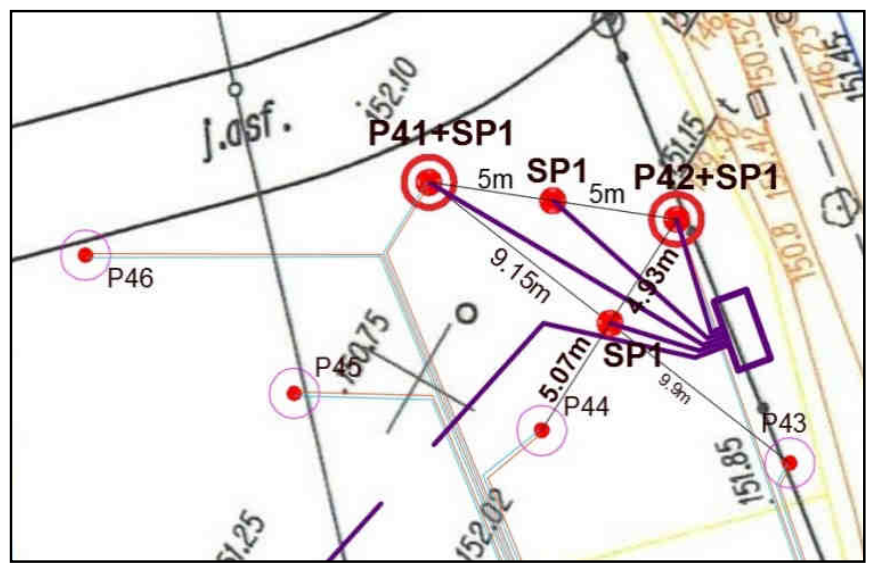

Fig. 5. Schematic diagram of the test-stand to measure the temperature in the vertical ground probes (P41, P42) and in the ground, and the location of the sensors (SP1-s) [48]

Each of probes SP1 shown in Figure 5 consist of 30 temperature sensors DS18B20 Dallas Company. Temperature sensors in measuring probes are arranged in the following distances from each other: on the section 0 to $1.0 \mathrm{~m}$ at $0.2 \mathrm{~m}$; on the section from $1 \mathrm{~m}$ to 
$3 \mathrm{~m}$ at $0.5 \mathrm{~m}$; on the section from $3 \mathrm{~m}$ to $13 \mathrm{~m}$ at $1 \mathrm{~m}$; on the section from $13 \mathrm{~m}$ to $15 \mathrm{~m}$ at $2 \mathrm{~m}$; on the section from $15 \mathrm{~m}$ to $30 \mathrm{~m}$ at $5 \mathrm{~m}$ and $30 \mathrm{~m}$ stretch of $100 \mathrm{~m}$ at $10 \mathrm{~m}$.

The measuring probe to measure the temperature distribution around the vertical ground probes shown in Figure 6 - the black cord, was introduced together with the vertical made earlier ground probe to the borehole with $160 \mathrm{~mm}$ diameter and a depth of $100 \mathrm{~m}$. After the introduction of the vertical ground heat exchanger and a probe with 30 sensors borehole has been filled tightly with a mixture of gravel - bentonite.

Geological profile of the ground [49] as follows: at a depth of up to $2 \mathrm{~m}$ Below Ground Level (BGL) is the native land, from $2 \mathrm{~m}$ to $4 \mathrm{~m}$ BGL sandy loam, from $4 \mathrm{~m}$ to $12 \mathrm{~m}$ below the surface there are sand and gravel, from $40 \mathrm{~m}$ to $45 \mathrm{~m}$ below the surface there are muds, from $45 \mathrm{~m}$ to $100 \mathrm{~m}$ BGL there are clay. The project has not been designated a geological usable aquifer. In contrast, on the basis of two shots in Bialystok away from the projected area of $640 \mathrm{~m}$ (intake 1) and $700 \mathrm{~m}$ (intake 2) [51], the depth of the water level is: for intake 1-23.7 m; for intake 2-24.5 m, while the level of the aquifer is: for intake $1-52 \mathrm{~m}$ and $8 \mathrm{~m}$ thickness; for intake of 2-36 m and thickness $23 \mathrm{~m}$ and $104 \mathrm{~m}$ and thickness of $14 \mathrm{~m}$.

A very important element in the performance of lower heat source are properly filled in the borehole in which the vertical probe is placed. The filler material is designed to ensure proper heat exchange between the probe and the soil layers and protect any water-bearing zone. The mixture should be frost-resistant, high thermal conductivity preferably $\lambda \geq 2 \mathrm{~W} /(\mathrm{m} \cdot \mathrm{K})$. When filling the hole, drilling fluid should not be used as it does not ensure proper bonding of the probe with the soil. The large proportion of bentonite in the scrubbers, which is characterized by shrinkage during drying, creates empty air spaces around the vertical geothermal probes.

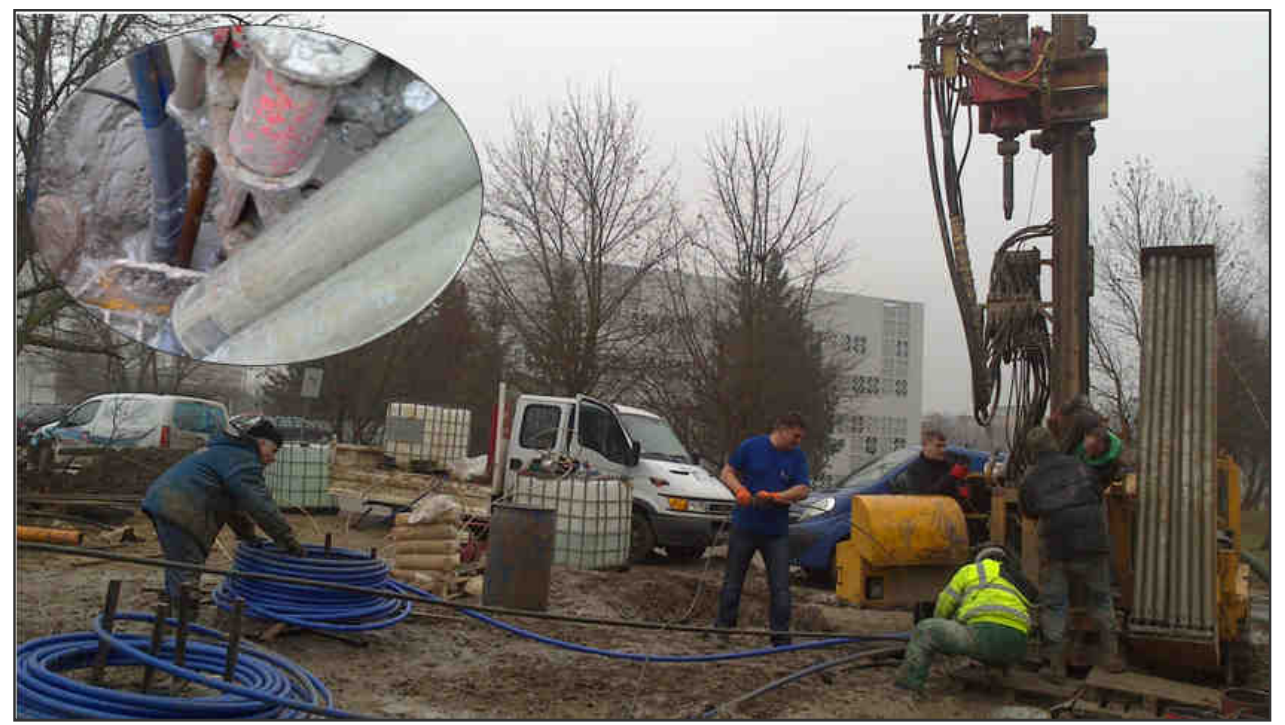

Fig. 6. Inserting the SP1 measuring probe (black wire), $100 \mathrm{~m}$ long, with 30 Dallas DS18B20 temperature sensors appropriately arranged, into the $\mathrm{P} 42$ borehole, together with the ground probe (blue) [photo: author] 
After all the earthworks and the installation works the lower heat source has been filled with thermal fluid glycerol based at a concentration of $40 \%$. Parameters of the used fluid is shown in Table 2.

Table 2

Parameters glycerol-based liquid used in the lower heat source

\begin{tabular}{|c|c|c|c|c|c|c|}
\hline \multirow{3}{*}{ Glycerol } & $\begin{array}{c}\text { Crystallization } \\
\text { temperature } \\
{[\mathbf{K}]}\end{array}$ & $\begin{array}{c}\text { Boiling } \\
\text { point }[\mathbf{K}]\end{array}$ & $\mathbf{p H}[-]$ & $\begin{array}{c}\text { Specific } \\
\text { gravity } \\
{\left[\mathbf{g} / \mathbf{c m}^{3}\right]}\end{array}$ & $\begin{array}{c}\text { Viscosity } \\
\mathbf{( 2 9 4 . 2} \mathbf{K}) \\
{[\mathbf{m P a} \cdot \mathbf{s}]}\end{array}$ & $\begin{array}{c}\text { Thermal } \\
\text { conductivity } \\
{[\mathbf{W} /(\mathbf{m} \cdot \mathbf{K})]}\end{array}$ \\
\cline { 2 - 7 } & 258.15 & 377.2 & $8.0-9.5$ & 1.09 & 3.39 & 0.500 \\
\hline
\end{tabular}

\section{Results and discussion}

Measurements of the temperature distribution in the two vertical ground probes $\mathrm{P} 41$ and $\mathrm{P} 42$ and an additional measurement of ground temperature in the vicinity of the probe is conducted in Bialystok (Poland), on the campus of BUoT. Characteristic for the studied area the average monthly temperature in each month and the number of days of the heating season and the average monthly rainfall values are given in Table 3.

The average annual temperature in Bialystok is $280.1 \mathrm{~K}$. Minimum average annual temperature is $256.3 \mathrm{~K}$. The number of heating days is 232 . The average daily humidity is $80 \%$. The number of degree-days in the heating season is 4095.4 day/(K·year).

Parameters characterizing the climate in the area of tests

\begin{tabular}{|c|c|c|c|c|c|c|c|c|c|c|c|c|}
\hline \multirow{2}{*}{$\begin{array}{c}\text { Town: Bialystok } \\
\text { [52] }\end{array}$} & \multicolumn{12}{|c|}{ Month } \\
\hline & I & II & III & IV & $\mathbf{V}$ & VI & VII & VIII & XI & $\mathbf{X}$ & XI & XII \\
\hline Temperature $[\mathrm{K}]$ & 268.3 & 271.2 & 274.9 & 280.5 & 286.3 & 289.1 & 290.5 & 287.7 & 285.3 & 280.3 & 274.8 & 271.9 \\
\hline $\begin{array}{l}\text { Number of } \\
\text { heating [ }\end{array}$ & 31 & 28 & 31 & 30 & 10 & 0 & 0 & 0 & 10 & 31 & 30 & 31 \\
\hline $\begin{array}{c}\text { Number of } \\
\text {,degree-days" of } \\
\text { heating season } \\
\text { [day/(K·year)] }\end{array}$ & 771.9 & 616.0 & 567.3 & 381.0 & 68.0 & 0 & 0 & 0 & 79.0 & 399.9 & 552.0 & 660.3 \\
\hline $\begin{array}{l}\text { Average monthly } \\
\text { rainfall [mm] }\end{array}$ & 32.8 & 26.5 & 33.4 & 34.0 & 63.6 & 68.8 & 75.1 & 65.7 & 56.1 & 41.3 & 41.0 & 38.2 \\
\hline
\end{tabular}

Temperature measurements are recorded continuously at intervals of 5 minutes. The research will be conducted by several heating seasons at depths: $1 \mathrm{~m} ; 1.5 \mathrm{~m} ; 2 \mathrm{~m} ; 3 \mathrm{~m}$; $4 \mathrm{~m} ; 5 \mathrm{~m} ; 6 \mathrm{~m} ; 7 \mathrm{~m} ; 8 \mathrm{~m} ; 9 \mathrm{~m} ; 10 \mathrm{~m} ; 11 \mathrm{~m} ; 12 \mathrm{~m} ; 13 \mathrm{~m} ; 15 \mathrm{~m} ; 20 \mathrm{~m} ; 25 \mathrm{~m} ; 30 \mathrm{~m} ; 40 \mathrm{~m}$; $50 \mathrm{~m} ; 60 \mathrm{~m} ; 70 \mathrm{~m} ; 80 \mathrm{~m} ; 90 \mathrm{~m}$ and a depth of $100 \mathrm{~m}$ with 30 digital temperature sensors DS18B20 Dallas Company connected to the 1-Wire bus. Probes have been installed for the first time at the end of December 2014. The paper presents the first recorded temperature measurements from the time of installation of measuring probes in the boreholes.

Mean daily temperature measurements at different depths in the borehole marked as P41 and P42 of the vertical ground probe working in the month of January - February are shown in Table 4. The results were averaged from the average daily measurements recorded every 5 minutes. 
Average daily temperature measurements at various depths in wells with $\mathrm{P} 41$ and $\mathrm{P} 42$ geothermal probes during heat pump operation in January - February in the heating season in 2015

\begin{tabular}{|c|c|c|c|c|c|}
\hline \multirow{3}{*}{$\begin{array}{c}\text { Depth } \\
\text { Below Ground } \\
\text { Level (BGL) [m] }\end{array}$} & \multirow{3}{*}{$\begin{array}{c}\text { Geological } \\
\text { profile of the } \\
\text { borehole BGL } \\
{[\mathrm{m}][52]}\end{array}$} & \multicolumn{2}{|c|}{ Borehole P41+SP1 } & \multicolumn{2}{|c|}{ Borehole P42+SP1 } \\
\hline & & \multicolumn{4}{|c|}{ Temperature $[\mathrm{K}]$} \\
\hline & & January & February & January & February \\
\hline 0.8 & \multirow{4}{*}{$\begin{array}{c}\text { Bank } \\
0-2 \text { m BGL }\end{array}$} & 276.2 & 276.4 & 276.1 & 275.3 \\
\hline 1.0 & & 276.9 & 276.9 & 276.8 & 275.8 \\
\hline 1.5 & & 277.9 & 277.5 & 277.7 & 276.6 \\
\hline 2.0 & & 279.1 & 278.4 & 278.5 & 277.0 \\
\hline 2.5 & \multirow{3}{*}{$\begin{array}{l}\text { Sandy loam } \\
2-4 \mathrm{~m} \text { BGL }\end{array}$} & 279.2 & 278.8 & 279.0 & 277.4 \\
\hline 3.0 & & 279.5 & 278.9 & 279.2 & 277.8 \\
\hline 4.0 & & 279.6 & 278.7 & 279.8 & 278.6 \\
\hline 5,0 & \multirow{8}{*}{$\begin{array}{l}\text { Sands and } \\
\text { Gravels } \\
\text { 4-12 m BGL }\end{array}$} & 279.7 & 278.5 & 279.5 & 278.7 \\
\hline 6.0 & & 280.2 & 278.7 & 279.6 & 279.0 \\
\hline 7.0 & & 279.6 & 279.2 & 279.5 & 279.5 \\
\hline 8.0 & & 279.1 & 279.0 & 279.1 & 279.2 \\
\hline 9.0 & & 278.9 & 278.7 & 278.9 & 278.7 \\
\hline 10.0 & & 278.3 & 278.1 & 278.8 & 278.9 \\
\hline 11.0 & & 278.7 & 278.7 & 278.7 & 278.5 \\
\hline 12.0 & & 278.5 & 278.6 & 278.5 & 277.9 \\
\hline 13.0 & \multirow{5}{*}{$\begin{array}{c}\text { Clay } \\
\text { 12-40 m BGL }\end{array}$} & 278.4 & 278.6 & 278.1 & 277.6 \\
\hline 15.0 & & 277.9 & 277.7 & 278.4 & 278.0 \\
\hline 20.0 & & 278.8 & 278.9 & 278.5 & 278.1 \\
\hline 25.0 & & 278.4 & 278.3 & 279.0 & 278.7 \\
\hline 30.0 & & 277.8 & 277.9 & 279.0 & 278.7 \\
\hline 40.0 & \multirow{2}{*}{$\begin{array}{c}\text { Muds 40-45 m } \\
\text { BGL } \\
\end{array}$} & 278.5 & 278.6 & 278.4 & 278.2 \\
\hline & & & & & \\
\hline 50.0 & \multirow{6}{*}{$\begin{array}{c}\text { Clay } \\
45-100 \mathrm{~m} \text { BGL }\end{array}$} & 278.5 & 278.5 & 278.4 & 278.0 \\
\hline 60.0 & & 278.5 & 278.8 & 279.7 & 279.3 \\
\hline 70.0 & & 279.0 & 279.0 & 279.7 & 279.3 \\
\hline 80.0 & & 278.9 & 278.8 & 279.5 & 279.0 \\
\hline 90.0 & & 279.3 & 279.2 & 279.6 & 279.1 \\
\hline 100.0 & & 279.3 & 279.4 & 279.5 & 279.2 \\
\hline
\end{tabular}

Figure 7 shows the selected daily temperature distribution in the ground at three depths in the borehole with ground probe marked as P41 (shown in Figs. 1 and 5) on 07/01/2015 for temperature measurements every 5 minutes, when the heat pump was working.

When the heat pump is turned on, a drop in temperature in the borehole can be observed at various time intervals throughout the day. It is related to the heat removal from the ground through the working medium flowing in the probe during the heat pump operation.

In the heat source are installed two pumps with a capacity of $117.2 \mathrm{~kW}$ each with coefficient given by the manufacturer $C O P=4.80$ (for $35^{\circ} \mathrm{C}$ of water and $0{ }^{\circ} \mathrm{C}$ of brine (W35/B0) according to PN-EN 14511-4:2018-08 [53]). Heat pumps are equipped with two compressors, which are designed to reduce the length of cycle on and off. During the months of January - February MASTER heat pump the first compressor total operating time was HP1 $=872$ hours and the second compressor was HP2 $=503$ hours, SLAVE heat pump worked fewer hours during these months, where the total number of hours worked was 
HP1 $=327$ hours for the first compressor and HP2 $=617$ hours for the second. Months January-February are the coldest months of the heating season in the north - eastern Poland. The exact working time of the compressors of heat pumps MASTER and SLAVE are given in Table 5.

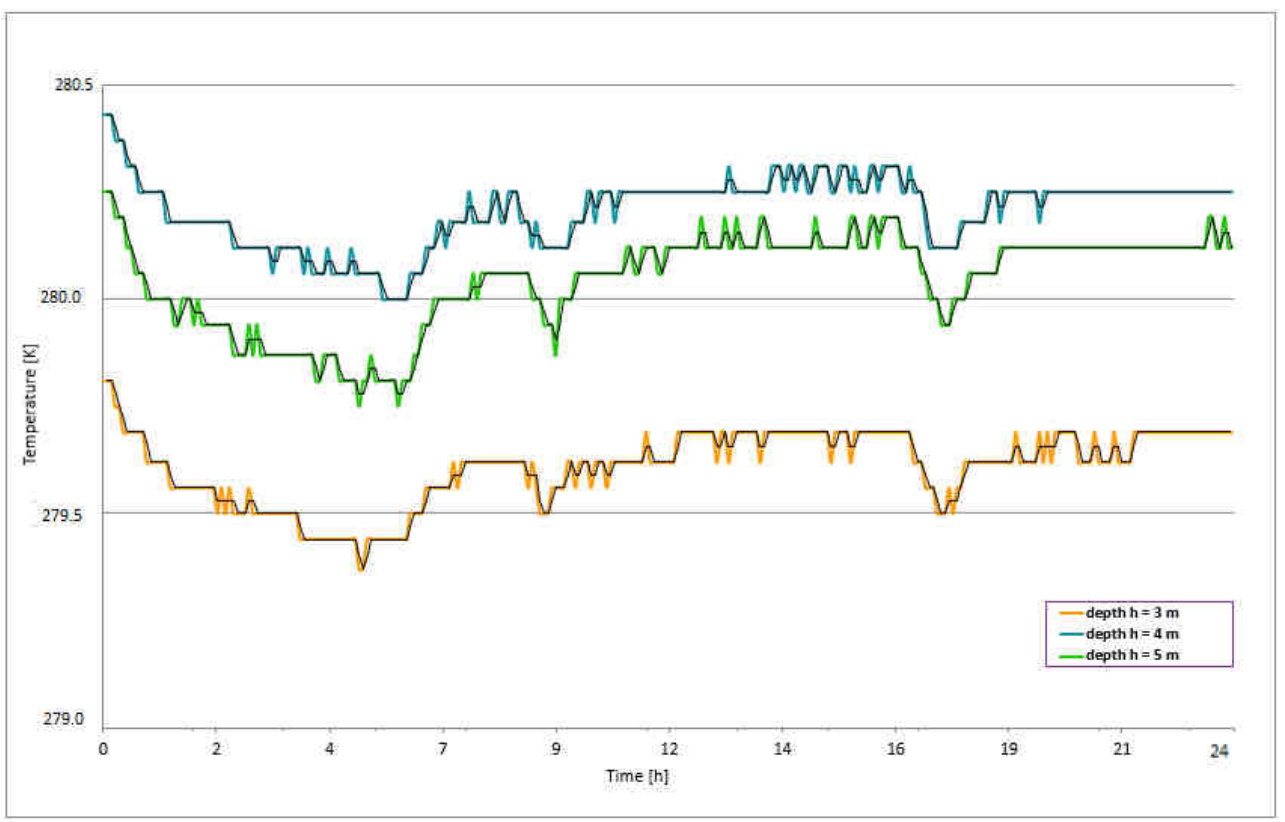

Fig. 7. Daily temperature distribution on the three selected depths measured on $07 / 01 / 2015$ in the borehole P41 with a working geothermal probe

Table 5

The heat pump compressor working time (MASTER and SLAVE) for individual weeks in the month of January and February

\begin{tabular}{|c|c|c|c|c|}
\hline \multirow{2}{*}{ Week } & \multicolumn{2}{|c|}{$\begin{array}{c}\text { Running time of the heat pump } \\
\text { compressor MASTER [hours] }\end{array}$} & \multicolumn{2}{c|}{$\begin{array}{c}\text { Running time of the heat pump } \\
\text { compressor SLAVE [hours] }\end{array}$} \\
\cline { 2 - 5 } & HP1 & HP2 & HP1 & HP2 \\
\hline 1 & 131 & 0 & 164 & 28 \\
\hline 2 & 166 & 0 & 100 & 73 \\
\hline 3 & 96 & 23 & 0 & 96 \\
\hline 4 & 79 & 80 & 0 & 77 \\
\hline 5 & 76 & 77 & 0 & 99 \\
\hline 6 & 97 & 98 & 0 & 90 \\
\hline 7 & 89 & 89 & 0 & 74 \\
\hline 8 & 86 & 85 & 11 & 0 \\
\hline 9 & 52 & 51 & 52 & $\mathbf{6 1 7} \mathbf{~ h}$ \\
\hline Total & $\mathbf{8 7 2} \mathbf{~ h}$ & $\mathbf{5 0 3} \mathbf{~}$ & $\mathbf{3 2 7} \mathbf{~}$ & \\
\hline
\end{tabular}

The average coefficient of performance of the heat pump $C O P_{H P}$ was in January $C O P_{H P I}=3.83$, while in February $C O P_{H P I I}=3.58$. $C O P_{H P}$ values were calculated based on 
the energy balance of the heat pump, the ratio of heat produced by the heat pump $Q_{H P}$ to the amount of electricity consumed to produce it only by the heat pump $E_{E L}$. The amount of electricity consumed for auxiliary devices, i.e.: circulation pumps, drives to the three-way valve actuators, automation was not included.

The efficiency of the heat pump was calculated from the formula:

$$
C O P_{H P}=\frac{Q_{H P}}{E_{E L}}
$$

where: $Q_{H P}$ - the amount of thermal produced by the heat pump [kWh], $E_{E L}$ - the amount of electricity consumed by the heat pump [kWh].

a)

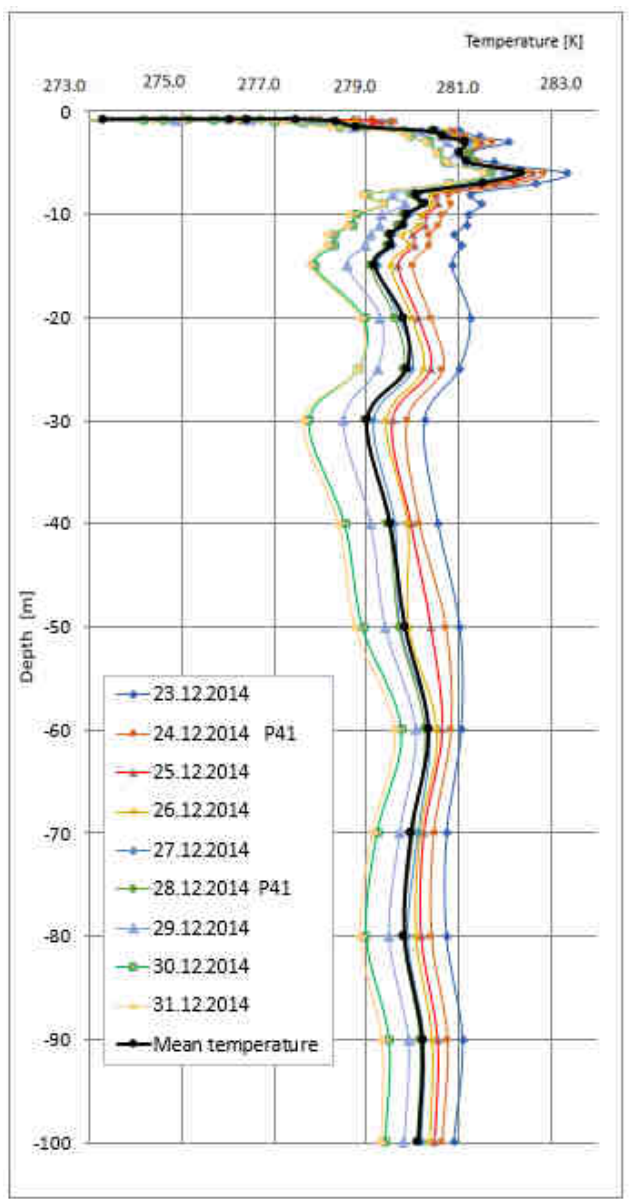

b)

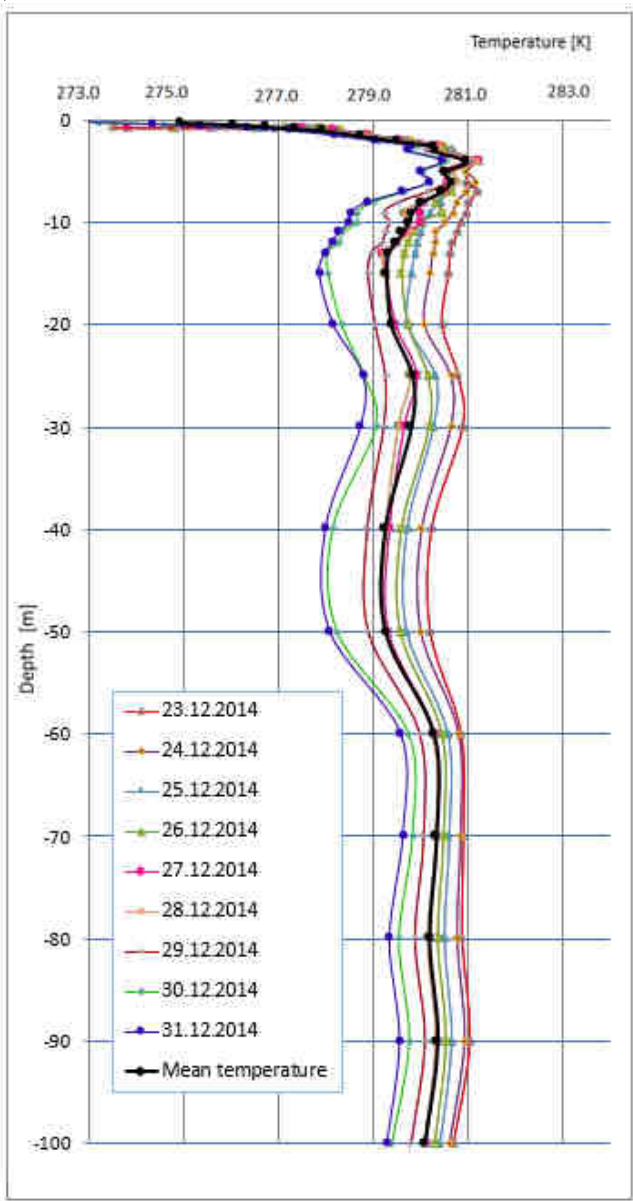

Fig. 8. The temperature distribution at different depths at vertical ground probes: a) P41 and b) P42 in December after starting the heat pump (23/12-31/12/2014) 
In the month of January, the amount of heat given out by the heat pump was $Q_{H P I}=44310 \mathrm{kWh}$ when taken of electricity $E_{E L I}=11573 \mathrm{kWh}$. While in February the amount of heat given out by the pump was $Q_{H P I I}=31119 \mathrm{kWh}$ when taken of electricity $E_{E L I I}=8693 \mathrm{kWh}$. Pump efficiency factor of two months (January - February), of its work is $C O P_{H P I, I I}=3.72$.

Figure 8 presents the temperature distribution at different depths from $0.8 \mathrm{~m}$ to $100 \mathrm{~m}$ at vertical ground probes P41 and P42 in December after starting the heat pump.

Initial start of the heat pump on the campus of BUoT occurred on 23/12/2014. Every day, heat pump operating can be seen the lowering of the temperature throughout the wellbore as compared to the first run of the heat pump is probably associated with the receipt heat stored in the ground and a decrease in undisturbed, natural temperature of the ground. At a depth of $15 \mathrm{~m}$ in borehole P41 temperature has changed since the start of the heat pump until 31/12/2014 of $2.2 \mathrm{~K}$, while in the borehole P42 of $2.3 \mathrm{~K}$. At a depth of $100 \mathrm{~m}$ temperature in the borehole $\mathrm{P} 41$ and $\mathrm{P} 42$ has changed by $1.3 \mathrm{~K}$. Average temperature throughout the wellbore $\mathrm{P} 41$ changed by $1.8 \mathrm{~K}$ and $1.6 \mathrm{~K}$ in wellbore $\mathrm{P} 42$.

Temperature distribution for each day in the month of January, in the vertical ground probes when the heat pump is working in the borehole P41 and P42 is shown in Figure 9.

a)

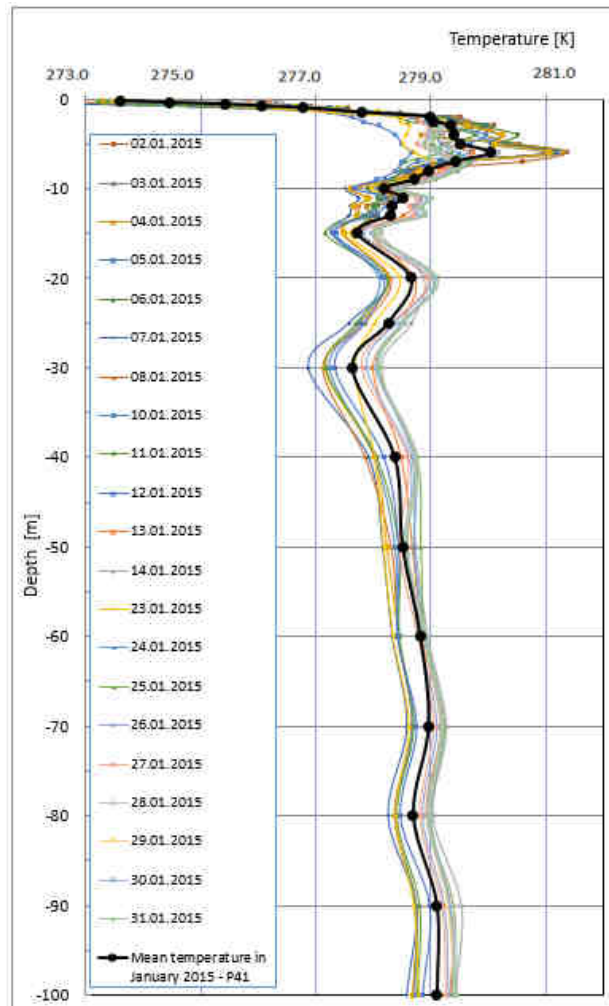

b)

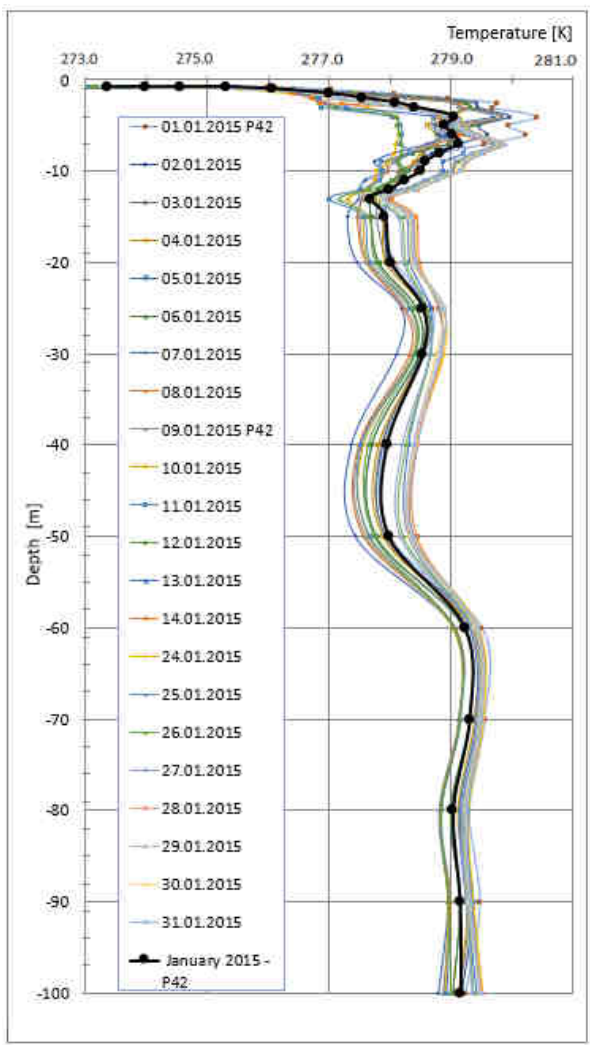

Fig. 9. The course of temperature changes in two wells marked as: a) P41 and b) P42 during the heat pump operation in January 
Depending on the glycol flow in the probe and the probe's working time on individual days, an increasing drop in soil temperature in the well with the ground probe can be observed.

The temperature is also variable along the entire depth of the well. The highest temperature changes are noticeable in the shallower layers, both in the P42 and P41 probes, where frost penetration took place, it is related to the quick reaction of the subsurface zone to short-term and diurnal weather. At a depth of $0.8 \mathrm{~m}$, the recorded temperature on January 6-8, 2015 in the P41 well was negative from 269.1 to $271.3 \mathrm{~K}$, which was related to low external temperatures.

At a depth below $12 \mathrm{~m}$, both in the $\mathrm{P} 41$ and $\mathrm{P} 42$ probe, the impact of temperature changes is not as great as in the shallow soil layer, it increases slowly with depth, due to the thermal effect of the Earth, according to the geothermal gradient. In the case of the P42 probe at a depth of about $40 \mathrm{~m}$ to $50 \mathrm{~m}$, a change in temperature in the well is noticeable, such a reduction may be due to the presence of silt at this depth, which results in better heat dissipation from the ground and higher efficiency of the vertical probe. A similar change can be seen in the $\mathrm{P} 41$ probe, but at a depth of about $30 \mathrm{~m}$.

In January, the average monthly temperature in the entire P41 well during the heat pump operation was $278.3 \mathrm{~K}$, while in the $\mathrm{P} 42$ one was $278.0 \mathrm{~K}$. The flow in the P41 probe was $26.0 \mathrm{dm}^{3} / \mathrm{min}$, while in the $\mathrm{P} 42$ probe it was $25.0 \mathrm{dm}^{3} / \mathrm{min}$. Flow change by $1.0 \mathrm{dm}^{3} / \mathrm{min}$ slightly affects the average temperature in the entire well. According to the technical design, the flow in the probes should be maintained at the level of $14.2 \mathrm{dm}^{3} / \mathrm{min}$, which would allow to maintain a temperature difference of the brine at the inlet and outlet of the heat pump of $4.0 \mathrm{~K}$. However, based on the recorded brine temperature measurements at the inlet and outlet of the heat pump, the difference temperatures in January and February amounted to $3.0 \mathrm{~K}$.

Neglecting the proper hydraulic adjustment of the installation with vertical geothermal probes may result in uneven exploitation of the heat source and individual wells. This may have a negative impact on the soil regeneration process around the ground heat exchanger pipes in the spring and summer period when the heat pumps are not working. Some heavily depleted wells may not fully recover during the spring and summer period, and if the uneven exploitation of the wells is maintained for a long time, it may lead to exploitation, freezing and, as a result, to "shutting down" the overloaded well from work.

The temperature distribution on individual days, in February, in vertical geothermal probes during the operation of the heat pump in the well with P41 and P42 geothermal probes is shown in Figure 10.

In February, lower temperatures were recorded in the near-surface zone during the operation of the vertical probe well than in January, which was related to the lower external temperature in February compared to January.

The monthly average temperature in the entire P41 well in February was 278.2 K, while in the P42 well it was $277.9 \mathrm{~K}$.

The average monthly temperature distribution in the well with P41 and P42 probes during the operation of the vertical ground probe in January and February in the heating season of 2015 and in the first weeks of the heat pump operation in December, along with the soil profile not loaded with the heat pump operation, is shown in Figure 11.

At the end of December 2014 was the first run of the heat pump. Pumps worked less than a week on and off, the compressor operating time was 142 hours. In January, the compressor worked 1269 hours in total, and in February 1050 hours. 
a)

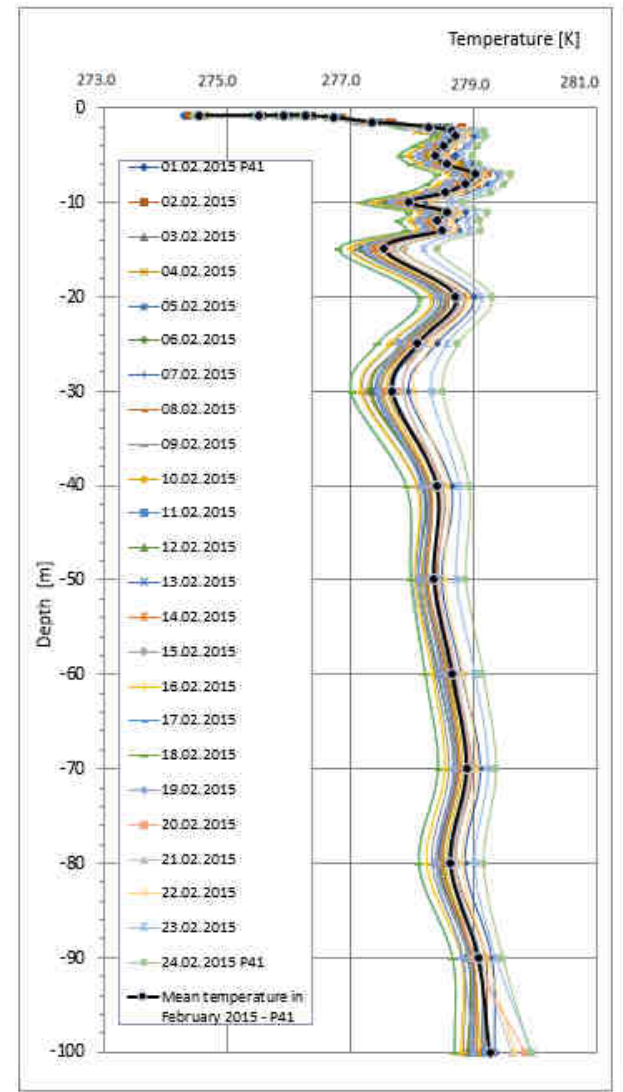

b)

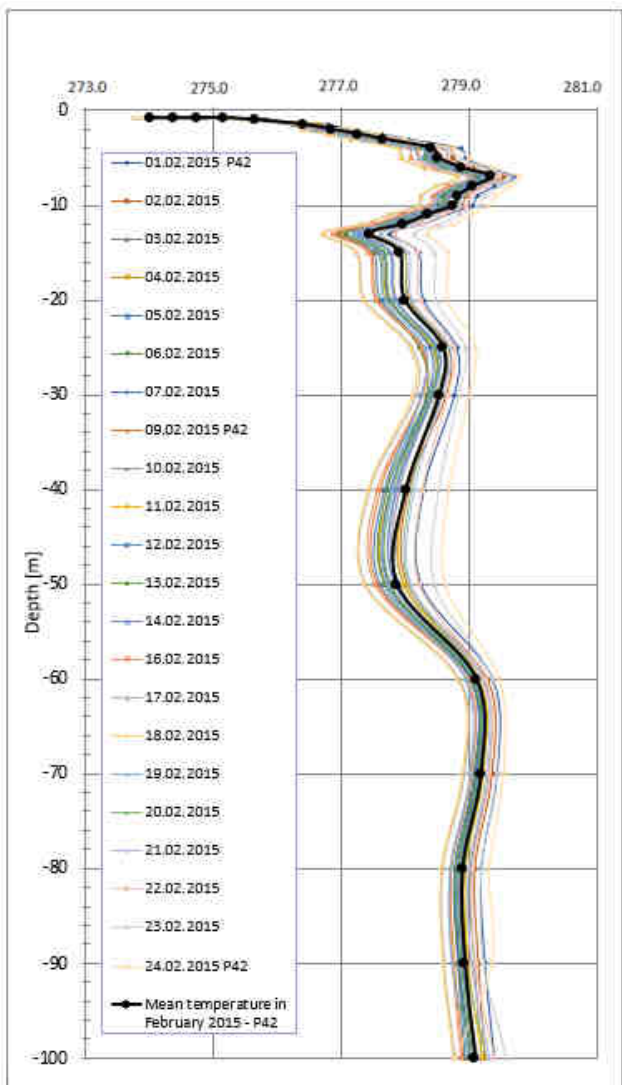

Fig. 10. The course of temperature changes in two wells marked as: a) P41 and b) P42 during the heat pump operation in February

From the graph on Figure 11 it can be seen that there has been a decrease of the ground temperature, compared to the ground unloaded operation of the heat pump. During the months of January - February is a further decrease in ground temperature associated with longer heat pump operation.

Depending on the depth and temperature changes occurring there, various soil divisions can be found, firstly, the boundary ones in the surface layer with intense temperature fluctuations - reaching a depth of about $1 \mathrm{~m}$. In this layer, significant temperature changes occur, and at low external temperatures the soil freezes. Secondly, the damped zone of temperature fluctuations - its depth can reach up to about $10 \mathrm{~m}$. Temperature changes caused by the influence of the external climate are significantly damped and delayed in relation to the climate changes that cause them the maximum deviation from the average annual decrease approximately exponentially with depth. And finally, there is a third area of almost constant temperature at depths exceeding $10 \mathrm{~m}$. 


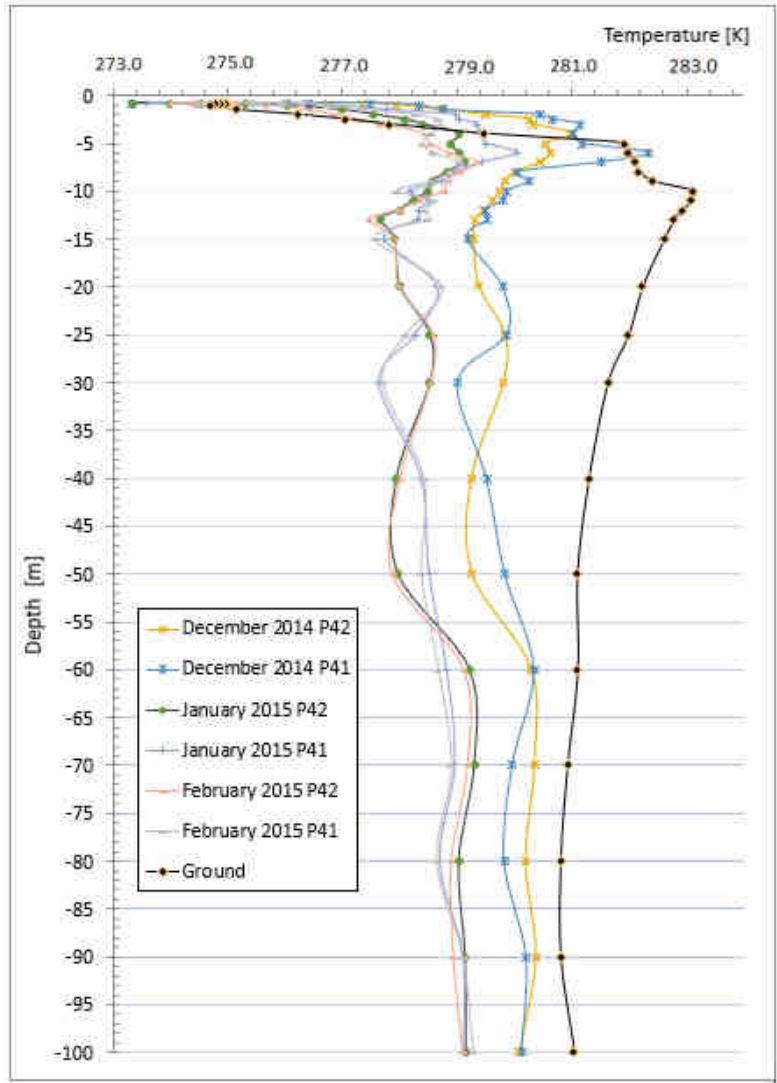

Fig. 11. The average monthly temperature distribution in a borehole $\mathrm{P} 41$ and $\mathrm{P} 42$ during operation vertical ground probe in the months of January and February and the first weeks of operation of the heat pump in the month of December and the temperature profile without work of heat pump

The wellbore P41 in the months of January - February compared to the ground temperature unloaded heat pump operation average temperature difference at the depth from 0.8 to $8 \mathrm{~m}$ was $2.1 \mathrm{~K}$, at the depth from $9 \mathrm{~m}$ to $15 \mathrm{~m}$ on average $4.5 \mathrm{~K}$, at depth from $20 \mathrm{~m}$ to $30 \mathrm{~m}$ on average $3.8 \mathrm{~K}$, and from $40 \mathrm{~m}$ to $100 \mathrm{~m}$ on average $2.3 \mathrm{~K}$. The wellbore P42 in the months of January - February compared to the ground temperature unloaded heat pump operation average temperature difference at the depth from 0.8 to $9 \mathrm{~m}$ was $1.8 \mathrm{~K}$, at the depth from $10 \mathrm{~m}$ to $20 \mathrm{~m}$ on average $4.7 \mathrm{~K}$, at depth from $30 \mathrm{~m}$ to $50 \mathrm{~m}$ on average $3.3 \mathrm{~K}$ and from $60 \mathrm{~m}$ to $100 \mathrm{~m}$ on average $1.8 \mathrm{~K}$.

\section{Conclusion}

1. On the basis of temperature measurements carried out from December to February, in two 100 m deep wells marked in Figure 1 as P41 and P42 with operating geothermal probes, a significant drop in temperature was found between the soil profile loaded with heat pumps and the soil profile with undisturbed temperature. The average soil temperature during the measurement period in the well without the heat pump 
operation was $280.2 \mathrm{~K}$. In January, the temperature in the P41 borehole with the operating geothermal probe dropped on average by about $2.6 \mathrm{~K}$ in relation to the average soil temperature. without heat pump operation, while in February it was $2.7 \mathrm{~K}$. In turn, in the P42 well the temperature differed by approx. $2.6 \mathrm{~K}$ in January and approx. $2.4 \mathrm{~K}$ in February from the average temperature of the thermally unloaded ground.

2. The undisturbed ground temperature profile, compared to wells with working probes, shows higher temperatures due to the lack of heat reception from the ground.

3. The average coefficient of heat pump operation efficiency in January was $C O P_{H P I}=3.83$, and in February $C_{H P} O P_{H I}=3.58$, and the obtained average coefficient of heat pump operation for two months was $C O P_{H P I, I I}=3.72$. The factor significantly differs from the factor provided by the manufacturer of the heat pump of $C O P=4.80$. The discrepancy between the calculated factors and those given by the manufacturer results, among others, from other brine parameters during operation of the heat pump and insufficient hydraulic adjustment of the brine system.

4. The installation of the lower heat source should always be hydraulically adjusted, and the flows determined on individual ground probes should be consistent with the technical design of the heat pumps. Only proper hydraulic adjustment will ensure proper heat reception from the ground and failure-free operation of the installation. Improper hydraulic adjustment can lead to uneven use of the ground heat source and heat energy gain from individual vertical geothermal probes. On the basis of the tests performed, it is recommended to adjust the hydraulic adjustment of the heat source system, in accordance with the technical design, so that the flow through each ground probe was $14.2 \mathrm{dm}^{3} / \mathrm{min}$.

5. Due to the high costs of drilling and measuring the wells, the tests of temperature distribution in the ground and in wells with operating geothermal probes are very expensive tests. Therefore, the obtained test results can be used to verify the numerical temperature fields around vertical geothermal probes and at the stage of designing geothermal heat exchangers.

\section{Acknowledgements}

The study has been implemented from the resources of the WZ/WB-IIŚ/4/2020 and S/WBiIS/4/2014 statutory work financed by the Ministry of Science and Higher Education in Poland and the project "Study the effectiveness of active and passive methods to improve the energy efficiency of the infrastructure from renewable energy sources" within the Regional Operational Programme 2007-2013 Podlaski Priority Axis I. Increased innovation and promote entrepreneurship in the region 1.1 Creating the conditions for innovation B-DO-120.362/40/14.

\section{References}

[1] Zhao Y, Pang Z, Huang Y., Ma Z. An efficient hybrid model for thermal analysis of deep borehole heat exchangers. Geotherm Energy. 2020;8(18). DOI: 10.1186/s40517-020-00170-z.

[2] Rad FM, Fung AS, Leong WH. Feasibility of combined solar thermal and ground source heat pump systems in cold climate, Canada. Energy Build. 2013;61:224-32. DOI: 10.1016/j.enbuild.2013.02.036.

[3] Minaei A, Maerefat M. A new analytical model for short-term borehole heat exchanger based on thermal resistance capacity model. Energy Build. 2017;146:233-42. DOI: 10.1016/j.enbuild.2017.04.064. 
[4] Rad FM, Fung AS, Rosen MA. An integrated model for designing a solar community heating system with borehole thermal storage. Energy Sustain Dev. 2017;36:6-15. DOI: 10.1016/j.esd.2016.10.003.

[5] Rad FM, Fung AS. Solar community heating and cooling system with borehole thermal energy storage review of systems. Renew Sustain Energy Rev. 2016;60:1550-61. DOI: 10.1016/j.rser.2016.03.025.

[6] Liu Z, Li R, Wang D, Li H, Shi L. Multilayer quasi-three-dimensional model for the heat transfer inside the borehole wall of a vertical ground heat exchanger. Geothermics. 2020;83:101711. DOI: 10.1016/j.geothermics.2019.101711.

[7] De Paly M, Hecht-Méndez J, Beck M, Blum P, Zell A, Bayer P. Optimization of energy extraction for closed shallow geothermal systems using linear programming. Geothermics. 2012;43:57-65. DOI: 10.1016/j.geothermics.2012.03.001.

[8] Zhao J, Wang H, Li X, Dai C. Experimental investigation and theoretical model of heat transfer of saturated soil around coaxial ground coupled heat exchanger. Appl Therm Eng. 2008;28:116-25. DOI: 10.1016/j.applthermaleng.2007.03.033.

[9] Zoras S, Dimoudi A, Kosmopoulos P. Analysis of conductive temperature variation due to multi-room underground interaction. Energy Build. 2012;55:433-8. DOI: 10.1016/j.enbuild.2012.08.033.

[10] Al-Temeemi A, Harris D. The generation of subsurface temperature profiles for Kuwait. Energy Build. 2001;33:837-41. DOI: 10.1016/S0378-7788(01)00069-X.

[11] Ouzzane M, Eslami-Nejad P, Aidoun Z, Lamarche L. Analysis of the convective heat exchange effect on the undisturbed ground temperature. Solar Energy. 2014;108:340-347. DOI: 10.1016/j.solener.2014.07.015.

[12] Pan A, Lu L, Tian Y. A new analytical model for short vertical ground heat exchangers with Neumann and Robin boundary conditions on ground surface. Int $J$ Thermal Sci. 2020;152:106326. DOI: 10.1016/j.ijthermalsci.2020.106326.

[13] Nian Y, Wang X, Xie K, Cheng W. Estimation of ground thermal properties for coaxial BHE through distributed thermal response test. Renew Energy. 2020;152:1209e1219. DOI: 10.1016/j.renene.2020.02.006.

[14] Boban L, Soldo V, Fuji H. Investigation of heat pump performance in heterogeneous ground. Energy Convers Manage. 2020;211:112736. DOI: 10.1016/j.enconman.2020.112736.

[15] Ahmadfard M, Bernier M. A review of vertical ground heat exchanger sizing tools including an intermodel comparison. Renew Sustain Energy Rev. 2019;110:247-65. DOI: 10.1016/j.rser.2019.04.045.

[16] Sailer E, Taborda DMG, Zdravković L. A new approach to estimating temperature fields around a group of vertical ground heat exchangers in two-dimensional analyses. Renew Energy. 2018; 118:579e590. DOI: 10.1016/j.renene.2017.11.035.

[17] Hu J. An improved analytical model for vertical borehole ground heat exchanger with multiple-layer substrates and groundwater flow. Appl Energy. 2017;202:537-49. DOI: 10.1016/j.apenergy.2017.05.152.

[18] Morchio S, Fossa M. On the ground thermal conductivity estimation with coaxial borehole heat exchangers according to different undisturbed ground temperature profiles. Appl Therm Eng. 2020;173:115198. DOI: 10.1016/j.applthermaleng.2020.115198.

[19] Beier RA. Thermal response tests on deep borehole heat exchangers with geothermal gradient, Appl Therm Eng. 2020;178:115447. DOI: 10.1016/j.applthermaleng.2020.115447.

[20] Gónzález-Santander JL. Asymptotic expansions for the ground heat transfer due to a borehole heat exchanger with a Neumann boundary condition. J Eng Math. 2019;117:47-64. DOI: 10.1007/s10665-019-10007-9.

[21] Kerme ED, Fung AS. Heat transfer simulation, analysis and performance study of single U-tube borehole heat exchanger. Renew Energy. 2020;145:1430-48. DOI: 10.1016/j.renene.2019.06.004.

[22] Bakirci K. Evaluation of the performance of a ground-source heat-pump system with series GHE (ground heat exchanger) in the cold climate region. Energy. 2010;35:3088-96. DOI: 10.1016/j.energy.2010.03.054.

[23] Florides GA, Pouloupatis P, Kalogirou S, Messaritis V, Panayides I, Zomeni Z, et al. The geothermal characteristics of the ground and the potential of using ground coupled heat pumps in Cyprus. Energy. 2011; 36:5027-36. DOI: 10.1016/j.energy.2011.05.048.

[24] Luo J, Rohn J, Bayer M, Priess A, Wilkmann L, Xiang W. Heating and cooling performance analysis of a ground source heat pump system in Southern Germany. Geothermics. 2015;53:57-66. DOI: 10.1016/j.geothermics.2014.04.004.

[25] Sivasakthivel T, Murugesan K, Kumar S, Hu P, Kobiga P. Experimental study of thermal performance of a ground source heat pump system installed in a Himalayan city of India for composite climatic conditions. Energy Build. 2016;131:193-206. DOI: 10.1016/j.enbuild.2016.09.034.

[26] Sivasakthivel T, Philippe M, Murugesan K, Verma V, Hu P. Experimental thermal performance analysis of ground heat exchangers for space heating and cooling applications. Renew Energy. 2017; 113:1168-81. DOI: 10.1016/j.renene.2017.06.098.

[27] Zhai X, Cheng X, Wang R. Heating and cooling performance of a mini type ground source heat pump system. Appl Therm Eng. 2017;111:1366-70. DOI: 10.1016/j.applthermaleng.2016.03.117. 
[28] Atwany H, Hamdan MO, Abu-Nabah BA, Alami AH, Attom M. Experimental evaluation of ground heat exchanger in UAE. Renew Energy. 2020;159:538e546. DOI: 10.1016/j.renene.2020.06.073.

[29] Naicker SS, Rees SJ. Long-term high frequency monitoring of a large borehole heat exchanger array. Renew Energy. 2020;145:1528-42. DOI: 10.1016/j.renene.2019.07.008.

[30] Spitler J, Bernier M. Vertical borehole ground heat exchanger design methods. Ch. 2. In: Rees SJ, editor. Advances in Ground-Source Heat Pump Systems. Oxford: Woodhead Publishing; 2016: 29-61. DOI: 10.1016/B978-0-08-100311-4.00002-9.

[31] Kasuda T, Archenbach P. Earth temperature and thermal diffusivity at selected stations in the United States. Ashrae Trans. 1965;71(1). DOI: 10.6028/nbs.rpt.8972.

[32] Nian Y, Cheng W. Analytical g-function for vertical geothermal boreholes with effect of borehole heat capacity. Appl Therm Eng. 2018;140:733-44. DOI: 10.1016/j.applthermaleng.2018.05.086.

[33] Yu X, Li H, Yao S, Nielsen V, Heller A. Development of an efficient numerical model and analysis of heat transfer performance for borehole heat exchanger. Renew Energy. 2020;152:189-97. DOI: 10.1016/j.renene.2020.01.044.

[34] Wang C, Li H, Huang Z, Lu Y, Huang X, Gan L. A new heat transfer model for single U-pipe ground heat exchanger. Appl Therm Eng. 2019;154:400-6. DOI: 10.1016/j.applthermaleng.2019.03.115.

[35] Mihalakakou G, Santamouris M, Lewis J, Asimakopoulos D, Argiriou A. On the ground temperature below buildings. Solar Energy. 1995;55(5):355-62. DOI: 10.1016/0038-092X(95)00060-5.

[36] Ghoreish-Madiseh S, Kuyuk A, de Brito MAR. An analytical model for transient heat transfer in groundcoupled heat exchangers of closed-loop geothermal systems. Appl Therm Eng. 2019;150:696-705. DOI: 10.1016/j.applthermaleng.2019.01.020.

[37] Lin J. On the force-restore method for prediction of ground surface temperature. J Geophysic Res. 1980;85:3251-4. DOI: 10.1029/JC085iC06p03251.

[38] Olfmana MZ, Woodburya DA, Bartley J. Effects of depth and material property variations on the ground temperature response to heating by a deep vertical ground heat exchanger in purely conductive media. Geotermics. 2014;51:9-30. DOI: 10.1016/j.geothermics.2013.10.002.

[39] Saskia MM, Wallin E. Ground temperature profiles and thermal rock properties at Wairakei, New Zealand. Renew Energy. 2012;43:313-21. DOI: 10.1016/j.renene.2011.11.032.

[40] Esen H, Inalli M, Esen Y. Temperature distributions in boreholes of a vertical ground-coupled heat pump system. Renew Energy. 2009;34(12):2672-9. DOI: 10.1016/j.renene.2009.04.032.

[41] Beier RA, Acuña J, Mogensen P, Palm B. Transient heat transfer in a coaxial borehole heat exchanger. Geothermics. 2014;51:470-82. DOI: 10.1016/j.geothermics.2014.02.006.

[42] Rybach L, Eugster WJ. Sustainability aspects of geothermal heat pump operation, with experience from Switzerland. Geothermics. 2010;39:365-9. DOI: 10.1016/j.geothermics.2010.08.002.

[43] Rybach L, Sanner B. Ground-source heat pump systems the European experience. GHC Bull. 2000;21(1):16-26. Available from: http://sanner-online.de/media/art4.pdf.

[44] Ma ZD, Jia GS, Cui X, Xia ZH, Zhang YP, Jin LW. Analysis on variations of ground temperature field and thermal radius caused by ground heat exchanger crossing an aquifer layer. Appl Energy. 2020;276:115453. DOI: $10.1016 /$ j.apenergy.2020.115453.

[45] Michalski A, Klitzsch N. First field application of temperature sensor modules for groundwater flow detection near borehole heat exchanger. Geotherm Energy. 2019;7:37. DOI: 10.1186/s40517-019-0152-5.

[46] Adamovský D, Neuberger P, Adamovský R. Results of operational verification of vertical ground heat exchangers. Energy Build. 2017;152:185-93. DOI: 10.1016/j.enbuild.2017.07.015.

[47] Han C, Bill X. Performance of a residential ground source heat pump system in sedimentary rock formation. Appl Energy. 2016;164:89-98. DOI: 10.1016/j.apenergy.2015.12.003.

[48] Łapa M. Projekt wykonawczy. Przebudowa budynku WBiIŚ Politechniki Białostockiej wraz z budową wewnętrznej instalacji monitoringu w ramach projektu „Poprawa efektywności energetycznej infrastruktury PB z wykorzystaniem odnawialnych źródeł ciepła". Zakres: budowa instalacji pomp ciepła. [Executive project. Reconstruction of the WBiIS building of the Bialystok University of Technology together with the construction of an internal monitoring installation under the project "Improving the energy efficiency of the PB infrastructure using renewable heat sources", Scope: construction of the heat pump installation]. Developed by design Office Technika Grzewcza SOLARSYSTEM, Myślenice, 2014.

[49] Bigaj Z. Projekt robót geologicznych na wykonanie otworów wiertniczych w celu wykorzystania ciepła $\mathrm{z}$ ziemi. [Project of geological works for drilling boreholes to use heat from the earth]. Hydrogeological company PANGEA; Chrzanów: 2013.

[50] Jarmoc W. Projekt techniczny wielopunktowego systemu pomiaru i monitoringu temperatury. [Technical design of the multi-point temperature measurement and monitoring system]. Elektrokomplex company; Białystok: 2014. 
[51] Available from: https://archiwum.miir.gov.pl/strony/zadania/budownictwo/charakterystyka-energetycznabudynkow/dane-do-obliczen-energetycznych-budynkow-1 (Białystok ISO STAT. TXT) (accessed 22.06.2020).

[52] Krogulec E, Wierchowiec J. Mapa geologiczno-gospodarcza w skali 1 : 50 000, arkusz Białystok (339). [Geological and economic map in scale 1:50,000, sheet Bialystok (339)]. Developed by: PIG:2007.

[53] PN-EN 14511-4:2018-08 Air conditioners, liquid chillers and heat pumps for heating and cooling, and industrial process chillers, with electrically driven compressors - Part 4: Requirements. Available from: https://sklep.pkn.pl/pn-en-14511-4-2018-08e.html. 